\title{
MODUL PEMESINAN GERINDA BAGI SISWA SMK TEKNIK PEMESINAN DI DAERAH ISTIMEWA YOGYAKARTA
}

\author{
Fariz Hashfie Saputra ${ }^{1}$, Edy Purnomo ${ }^{2}$ \\ 1,2 Jurusan Pendidikan Teknik Mesin FT UNY \\ Email: farizhasfie@gmail.com
}

\begin{abstract}
This research and development aims to determine the feasibility level of module learning media of grinding theory and to determine the effectiveness of basic grinding theory to the academic achievement of class $X I$ students in the machining study program. The research methods is quantitative descriptive method. The results validates the use of grinding theory module in learning activities. The average percentage from the quality of content, instructional and technical, is $91,25 \%$. The effectiveness of basic grinding theory module can be seen from the improvement of students' marks of $97.28 \%$ in average. The increase in the active participation is $33.3 \%$.
\end{abstract}

Keywords: learning media, module, grind machining theory

\begin{abstract}
ABSTRAK
Penelitian pengembangan ini bertujuan untuk mengetahui kelayakan media pembelajaran modul teori pemesinan gerinda dan mengetahui tingkat efektivitas modul teori pemesinan gerinda terhadap hasil belajar siswa teknik pemesinan kelas XI SMK Muhammadiyah Prambanan. Penelitian ini menggunakan langkah Research and Development dan metode penelitian deskriptif kuantitatif. Hasil pada penelitian ini adalah media pembelajaran modul teori pemesinan gerinda dinyatakan layak digunakan untuk kegiatan pembelajaran dengan rerata persentase kelayakan kualitas isi, instruksional, dan teknis sebesar 91,25\%. Efektivitas media pembelajaran modul Teori Gerinda Dasar dapat dilihat dari peningkatan rerata hasil belajar sebesar 97,28\% dan peningkatan partisipasi aktif sebesar 33,3\%.
\end{abstract}

Kata kunci: media Pembelajaran, modul, teori pemesinan gerinda

\section{PENDAHULUAN}

Hasil Ujian Nasional (UN) SMK swasta di Kabupaten Sleman menunjukkan rerata sebesar 57.05. Rendahnya hasil UN tersebut disebabkan oleh berbagai aspek, salah satunya penggunaan media pembelajaran yang kurang tepat dalam kegiatan pembelajaran.

Sekolah Menengah Kejuruan (SMK) Muhammadiyah Prambanan merupakan salah satu sekolah kejuruan swasta di Kabupaten Sleman. Sekolah ini memiliki Program Keahlian Teknik Mesin khususnya Paket Keahlian Teknik Pemesinan. SMK Muhammadiyah Prambanan sudah menerapkan Kurikulum 2013 yang terdapat kompetensi teknik pemesinan gerinda didalamnya, Namun dalam pembelajarannya masih menggunakan metode ekspositori. Di sisi lain, kompetensi ini membutuhkan modul pembelajaran yang dapat digunakan dalam pembelajaran mandiri karena terbatasnya waktu pembelajaran. Selain itu, guru pengampu mengharapkan modul pembelajaran yang dapat diterapkan dengan metode pembelajaran inquiry agar siswa aktif dalam pembelajaran serta memahami kompetensi dengan cara belajarnya.

Selain itu, menurut peraturan Dirjen pendidikan dasar dan menengah Kemendikbud Nomor. 07/D.D5/KK/2018 tentang struktur kurikulum SMK/ MAK terdapat paket keahlian teknik pemesinan dalam bidang Teknologi dan Rekayasa. Kompetensi teknik pemesinan gerinda adalah kompetensi keahlian yang dibutuhkan oleh industri manufaktur saat ini. Produksi komponen dalam industri memerlukan teknik penggerindaan. Hal tersebut karena teknik penggerindaan meningkatkan nilai kriteria permukaan produk. Masih banyak SMK 
yang masih belum menggunakan modul pembelajaran dan metode pembelajaran pada bidang keahlian teknik pemesinan dalam mata pelajaran teknik pemesinan gerinda dengan baik. Selain itu, belum ada media pembelajaran yang cukup baik untuk menunjang kebutuhan pembelajaran maupun untuk pembelajaran mandiri teknik pemesinan gerinda.

Media pembelajaran cetak mengenai Teknik Pemesinan Gerinda sudah dikembangkan oleh Hadi Mursidi dan Tatang Rahmat (2013) yang diterbitkan melalui DPSMK. Selain itu, terdapat modul Bekerja dengan Mesin Gerinda yang dikembangkan oleh Umaryadi (2007). Kedua buku tersebut telah memenuhi kriteria kompetensi yang dibutuhkan serta dapat digunakan untuk pembelajaran di SMK. Namun, kedua media pembelajaran cetak tersebut belum dapat digunakan dalam pembelajaran mandiri dikarenakan masih terdapat materi yang perlu dipelajari dengan bimbingan guru. Selain itu, media pembelajaran tersebut tidak mendukung metode pembelajaran K13 dikarenakan tidak terdapat komponen dalam media pembelajaran yang mengarahkan siswa untuk merumuskan suatu permasalahan maupun dalam penentuan data dan penyusunan hipotesis.

Penelitian mengenai media pembelajaran modul yang diteliti dan dikembangkan oleh Nopriyanti (2018) dan Alfiata (2017) menunjukkan bahwa media pembelajaran modul tersebut layak digunakan dalam proses pembelajaran. Modul tersebut dapat digunakan untuk meningkatkan minat belajar siswa. Selain itu, modul tersebut dapat digunakan untuk pembelajaran mandiri.

Berdasarkan ulasan di atas, maka dikembangkan serta diteliti kelayakan dan efektivitas modul teori pemesinan gerinda di SMK Muhammadiyah Prambanan. Hasil penelitian ini diharapkan dapat memberikan manfaat bagi sekolah untuk sarana pembelajaran teori khususnya mata pelajaran Teknik Pemesinan Gerinda. sehingga dengan adanya modul yang layak dapat meningkatkan kompetensi keahlian siswa.

\section{METODE}

Penelitian ini menggunakan tahapan Research and Development (R\&D) yang dikembangkan oleh Sugiyono dengan sedikit modifikasi. Penelitian pengembangan ini menggunakan pendekatan Deskriptif Kuantitatif, yang difokuskan pada uji kelayakan dan efektivitas modul. Penelitian ini dilakukan di jurusan teknik pemesinan SMK Muhammadiyah Prambanan. Penelitian dan pengembangan adalah penelitian yang diawali dengan proses mengembangkan suatu produk atau menyempurnakan produk yang sudah ada (Sukoco, 2014). Langkah/ prosedur penelitian pengembangan dapat dilihat pada Gambar 1.

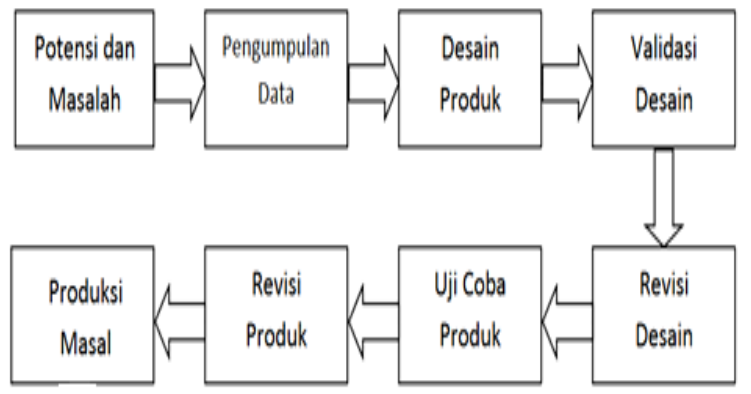

Gambar 1. Prosedur $R \& D$ modifikasi milik Sugiyono

Data yang dikumpulkan dalam penelitian ini berupa data kualitatif dan data kuantitatif. Data tersebut dikumpulkan dengan menggunakan instrumen berupa angket, dokumentasi dan tes formatif. Teknik analisis data dalam penelitian ini menggunakan analisis deskriptif kuantitatif untuk analisis kelayakan materi dan media.

\section{HASIL DAN PEMBAHASAN}

Analisis data dilakukan untuk mengetahui seberapa besar kriteria kelayakan modul Teori Gerinda Dasar yang sudah terpenuhi. Analisis data pada masing-masing kriteria kelayakan ini dilakukan berdasarkan 3 kualitas menurut Walker dan Hess (1984: 206) dalam Arsyad (2011:175) yaitu kualitasi isi, kualitas instruksional dan kualitas teknis. Analisis kelayakan tersebut ditentukan 
berdasarkan butir kelayakan angket. Butir yang digunakan tiap penilaian kualitas berbeda. Butir tersebut ditentukan reratanya kemudian diubah dalam bentuk skala penilaian.

Pengaruh kelayakan sebuah modul Teori Pemesinan Gerinda dengan kompetensi pengasahan beberapa alat potong terhadap hasil pembelajaran yang dicapai siswa dapat dikategorikan menjadi beberapa kualitas. Tabel 1 menunjukkan kelayakan modul berdasar kualitas isi, instruksional dan teknis. Keseluruhan kriteria penilaian menunjukkan nilai di atas 3.5 dan dalam klasifikasi kelayakan sangat baik.

Tabel 1. Skala Kelayakan Kualitas Modul

\begin{tabular}{lcl}
\hline Kriteria Penilaian & Skala & $\begin{array}{l}\text { Klasifikasi } \\
\text { Kelayakan }\end{array}$ \\
\hline Kualitas Isi & 3.61 & Sangat Baik \\
Kualitas Instruksional & 3.67 & Sangat Baik \\
Kualitas Teknis & 3.67 & Sangat Baik \\
\hline Jumlah & 3.65 & Sangat Baik \\
\hline
\end{tabular}

Penilaian dari segi materi oleh ahli materi mencakup 5 aspek yaitu kelayakan isi, kelayakan bahasa, kelayakan penyajian, efek media terhadap pembelajaran dan tampilan menyeluruh modul tersebut. Skor tersebut didapatkan dari validasi materi oleh seorang dosen ahli dan 5 guru pengampu pemesinan yang diakumulasikan dari jumlah butir instrumen sejumlah 30 butir.

Tabel 2. Hasil Validasi Ahli Materi

\begin{tabular}{lll}
\hline Aspek Penilaian & Skor & Skala \\
\hline Kelayakan Isi & 270 & 3.46 \\
Kelayakan Bahasa & 158 & 3.76 \\
Kelayakan Penyajian & 66 & 3.67 \\
Efek Media thdp Pemb. & 114 & 3.8 \\
Tampilan Menyeluruh & 46 & 3.83 \\
\hline Jumlah & 654 & 18.49 \\
\hline
\end{tabular}

Berdasarkan Tabel 2 di atas yang dikonversikan dalam skala likert dengan nilai 1-4 didapatkan total skor dari ahli materi sebesar 654. Total skor di atas merupakan 654 dari total skor 720. Jumlah skor tersebut dimasukkan pada perhitungan 1 kemudian didapatkan hasil akhir sebesar 90.83\%. Rerata tersebut dirubah dalam bentuk skala likert menjadi 3.63. Maka, kelayakan berdasarkan ahli materi dinyatakan layak dengan kategori sangat baik.

Pengembangan aspek kelayakan dapat dilakukan dengan menambah penjelasan isi materi pada setiap pembelajaran agar siswa semakin mudah menerima isi materi, memperjelas isi materi pada alur pembelajaran agar muatan isi pembelajaran lebih spesifik dan mudah dipahami siswa (Afiata, 2017). Berdasarkan data kualitatif yang didapat, selanjutnya dilakukan pengembangan dengan menambahkan Lembar Kerja Siswa (LKS) serta tes sumatif guna tolak ukur pemahaman siswa. Selain itu, LKS juga dapat digunakan sebagai variasi kegiatan pembelajaran dan dapat dilaksanakan diluar ruang kelas.

Penilaian dari segi media oleh ahli media mencakup 4 aspek yaitu kelayakan bahasa, kelayakan penyajian, efek media terhadap pembelajaran dan tampilan menyeluruh modul tersebut. Skor tersebut didapatkan dari validasi materi oleh seorang dosen ahli media yang diakumulasikan dari jumlah butir instrumen sejumlah 20 butir.

Tabel 3. Hasil Validasi Ahli Media

\begin{tabular}{lll}
\hline Aspek Penilaian & Skor & Skala \\
\hline Kelayakan Bahasa & 22 & 3.67 \\
Kelayakan Penyajian & 10 & 3.33 \\
Efek Media thdp Pemb. & 18 & 3.6 \\
Tampilan Menyeluruh & 22 & 3.67 \\
\hline Jumlah & 72 & 14.27 \\
\hline
\end{tabular}

Berdasarkan Tabel 3, kelayakan media berdasarkan aspek kelayakan bahasa, kelayakan penyajian, efek media terhadap pembelajaran, dan tampilan menyeluruh memiliki skor 72 dari 80. Jumlah skor tersebut dimasukkan dalam perhitungan 1 kemudian didapatkan hasil akhir sebesar 90\% atau sebesar 3.6 dalam skala likert. Maka, media pembelajaran modul dinyatakan layak dengan kategori sangat baik.

Efektivitas produk dapat dilihat dari hasil uji coba produk yang diperoleh dari tes formatif. Terjadi peningkatan partisipasi aktif 
siswa dalam pembelajaran. Hal tersebut dapat dilihat dari hasil observasi saat pembelajaran, siswa lebih mudah menangkap materi pembelajaran ketika media pembelajaran yang digunakan mendukung daya tangkap siswa terhadap materi. Pendukung daya tangkap materi yang dimaksud adalah ilustrasi gambar, penjelasan detail, serta bahasa yang mudah dipahami.

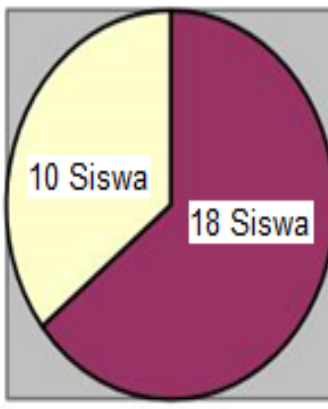

Uji Coba I

Tidak Lulus

Gambar 2. Diagram pie hasil uji coba evaluasi pembelajaran

Hasil peningkatan dapat dilihat pada Gambar 2. Hasil uji coba menunjukkan bahwa peningkatan rerata kelas sebesar 97,38\%. Selain terjadi peningkatan rerata kelas, partisipasi aktif siswa juga mengalami peningkatan dari 18 siswa mengikuti evaluasi pra modul tidak ada yang memenuhi Kriteria Ketuntasan Minimal (KKM). Sedangkan, pada evaluasi pasca penggunaan modul 21 dari 24 siswa yang mengikuti telah memenuhi KKM. Peningkatan partisipasi aktif siswa dilihat dari peningkatan jumlah siswa yang memenuhi KKM. Siswa yang memenuhi KKM diartikan berpartisipasi aktif dalam pembelajaran sehingga mampu memahami materi dan mengerjakan evaluasi pembelajaran. Peningkatan partisipasi aktif siswa dari pra modul ke pasca modul yaitu sebesar 33,3\%. Oleh karena itu, modul Teori Gerinda Dasar tersebut dapat dikatakan modul yang efektif dalam kegiatan pembelajaran.

\section{SIMPULAN}

Kelayakan media pembelajaran ditinjau dari 3 aspek kualitas (Rika, 2017). Data-data penilaian kelayakan media pembelajaran modul diperoleh dari validasi oleh dosen ahli materi, dosen ahli media dan 5 guru pengampu teknik pemesinan serta hasil uji coba evaluasi pembelajaran terhadap siswa. Berdasarkan hasil pengujian, kelayakan kualitas isi diperoleh skala kelayakan 3,61 dengan klasifikasi sangat baik. Penilaian kelayakan kualitas instruksional diperoleh skala kelayakan 3,67 dengan klasifikasi sangat baik. Penilaian kelayakan kualitas teknis diperoleh skala kelayakan 3,67 dengan klasifikasi sangat baik.

Efektivitas modul Teori Gerinda Dasar dengan kompetensi pengasahan alat potong di SMK Muhammadiyah Prambanan ini dapat dilihat dari hasil uji coba yang dilakukan. Terjadi peningkatan rerata kelas sebesar 97,38\% serta peningkatan partisipasi aktif dilihat dari segi peningkatan partisipan sebesar 33,3\%. Maka, Modul dinyatakan efektif berdasarkan peningkatan tersebut.

\section{DAFTAR RUJUKAN}

Andi Prastowo. (2012). Panduan Kreatif Membuat Bahan Ajar Inovatif. Yogyakarta: Diva Press.

Alfiata Donny Nuryanto dan Tiwan.(2017). Pengembangan Modul Pengecoran Logam Alumunium untuk Siswa Sekolah Menengah Kejuruan. Jurnal Vokasional Dinamika Teknik Mesin, 2 (2), 112-116.

Azhar Arsyad. (2011). Media Pembelajaran. Jakarta: PT Raja Grafindo Persada.

Hadi Mursidi dan Tatang Rahmat.(2013).Teknik

Pemesinan Gerinda 1.Cimahi : DPSMK

KEMENDIKBUD.

Kemendikbud. (2017). Kementrian Pendidikan dan Kebudayaan Nomor: 4540/D5.3/TU/2017 Tentang Pelaksanaan Kurikulum Pendidikan Menengah Kejuruan. 
Kemendikbud. (2018). Kementrian Pendidikan dan Kebudayaan Nomor: 07/D.D5/KK/2018 Tentang Struktur Kurikulum Sekolah Menengah Kejuruan(SMK)/ Madrasah Aliyah Kejuruan (MAK).

Nopriyanti. (2018). Pengembangan Modul Elektronik Berbasis 3D Pageflip Professional Mata Kuliah Gambar Teknik di Program Stude Pendidikan Teknik Mesin. Jurnal Vokasional Dinamika Teknik Mesin, 3 (1), 64-75.

Rika Dewi Indriyani, Tiwan, dan Dwi Rahdiyanta. (2017). Pengembangan Media Pembelajaran Pada Kompetensi Dasar Membaca Gambar Menerapkan Sistem Koordinat Berbasis Adobe Flash.
Jurnal Vokasional Dinamika Teknik Mesin, 2 (1), 59-64.

Sugiyono. (2011). Metode Penelitian Kuantitatif, Kualitatif, dan $R \& D$. Bandung: Alfabeta.

Sukoco, dkk.(2014). Pengembangan Media Pembelajaran Interaktif Berbasis Komputer Untuk Peserta Didik Mata Pelajaran Teknik Kendaraan Ringan. Jurnal Pendidikan Teknik dan Kejuruan, 22 (2), 222-225.

Umaryadi.(2007).Modul Bekerja Dengan Mesin Gerinda Teknologi \& Industri. Surakarta : Yudhistira.

Wardiman Djojonegoro. (1998). Pengembangan Sumber Daya Manusia Melalui SMK. Jakarta: Jayakarta Agung Offset. 